Original Article

\title{
Physiological and biochemical changes induced by Qiangdi nano-863 biological assistant growth apparatus during rice seed priming under temperature stress
}

\author{
Alterações fisiológicas e bioquímicas induzidas pelo aparelho de crescimento \\ assistente biológico Qiangdi nano-863 durante o priming de sementes de arroz sob \\ estresse de temperatura
}

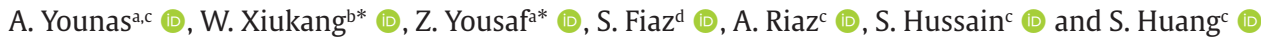 \\ aLahore College for Women University, Department of Botany, Lahore, Pakistan \\ 'College of Life Sciences, Yan'an University, Yan'an 716000, Shaanxi, China \\ 'China National Rice Research Institute, State Key Laboratory of Rice Biology, Hangzhou, China \\ dThe University of Haripur, Department of Plant Breeding and Genetics, Khyber Pakhtunkhwa, Pakistan
}

\begin{abstract}
A huge amount of rice cultivation and consumption occur in Asia particularly in Pakistan and China. However, multiple abiotic stresses especially high and low-temperature proved to be a substantial threat for rice production ultimately risks for food security. To overcome various types of abiotic stress; seed priming is among the effective approaches to improve the rice seed germination and growth vigor. Therefore, the present study was planned to evaluate physiological and biochemical modifications in Chinese and Pakistani rice varieties by Qiangdi 863 biological assistant growth apparatus nano treated water (NTW), Osmopriming Calcium chloride $\left(\mathrm{CaCl}_{2}\right)$, redox priming hydrogen peroxide $\left(\mathrm{H}_{2} \mathrm{O}_{2}\right)$ and hormonal priming by Salicylic acid (SA) under temperature stress conditions. The experiment was performed with completely randomize design conditions. Five rice varieties, nomenclature as Zhongzoa 39, (Chinese rice variety) KSK 133, KS 282, Super basmati and PK 1121 aromatic (Pakistani rice variety) were sown under low temperature $(\mathrm{LT})\left(17^{\circ} \mathrm{C}\right)$, optimal temperature $(\mathrm{OT}) 27^{\circ} \mathrm{C}$ and high temperature (HT) $37^{\circ} \mathrm{C}$ conditions. The present study indicated that nanopriming were the most effective treatments increased Germination Energy Percentage (GEP) (96.1, 100, 100\%), Speed of Germination (SG) (27.2, 35.45, 37.1), Final Germination Percentage (FGP) (98.2, 99.1, 99.4\%), Seedling Dry Weight Biomass (DWB) (0.1, 0.137, 0.14g), Total Chlorophyll Content $(0.502,13.74,15.21)$, antioxidant enzymes Superoxide Dismutase (SOD) $\left(3145,2559,3345 \mu \mathrm{g}^{-1} \mathrm{FWh}^{-1}\right)$,

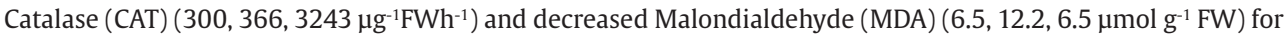
Zhongzao 39 and KSK 133 rice varieties under low ( $\mathrm{LT}+\mathrm{NTW})$, optimal temperature (OP+NTW) and high temperature $(\mathrm{HT}+\mathrm{NTW})$ stress., Therefore, nano-priming is recommended to cope with the high and low-temperature stress conditions along with improved productivity of rice.
\end{abstract}

Keywords: antioxidative enzymes, high temperature, low temperature, seed priming.

\begin{abstract}
Resumo
Cultivo e consumo de arroz ocorrem em grandes quantidades na Ásia, particularmente no Paquistão e na China. No entanto, vários estresses abióticos, especialmente de alta e baixa temperatura, provaram ser uma ameaça considerável para a produção de arroz, em última análise, riscos para a segurança alimentar. Para superar vários tipos de estresse abiótico, o priming de sementes está entre as abordagens eficazes que melhoram a germinação e o vigor de crescimento das sementes de arroz. Portanto, o presente estudo foi planejado para avaliar as modificações fisiológicas e bioquímicas em variedades de arroz chinês e paquistanês por Qiangdi 863, aparelho assistente biológico de crescimento com água nanotratada (NTW), Osmopriming cloreto de cálcio $\left(\mathrm{CaC}_{12}\right)$, peróxido de hidrogênio redox $\left(\mathrm{H}_{2} \mathrm{O}_{2}\right)$ e priming hormonal por ácido salicílico (SA) em condições de estresse de temperatura. $\mathrm{O}$ experimento foi realizado em condições de delineamento inteiramente ao acaso. Cinco variedades de arroz, nomenclaturas como Zhongzoa 39 (variedade de arroz chinês), KSK 133, KS 282, Super basmati e PK 1121 aromático (variedade de arroz do Paquistão) foram semeadas sob baixa temperatura (LT) $\left(17^{\circ} \mathrm{C}\right)$, temperatura ótima (OT) $27{ }^{\circ} \mathrm{C}$ e condições de alta temperatura (HT) $37^{\circ} \mathrm{C}$. O presente estudo indicou que nanocondicionamento foi o tratamento mais eficaz: aumento da porcentagem de energia de germinação (GEP) $(96,1 \%, 100 \%, 100 \%)$, velocidade de germinação (SG) $(27,2,35,45,37,1)$, porcentagem de germinação final (FGP) $(98,2 \%, 99,1 \%, 99,4 \%)$, biomassa de peso seco de mudas (DWB) $(0,1 \mathrm{~g}, 0,137 \mathrm{~g}, 0,14 \mathrm{~g})$, conteúdo total de clorofila $(0,502,13,74,15,21)$, enzimas antioxidantes superóxido
\end{abstract}

*e-mail: wangxiukang@yau.edu.cn; z4zubaida@yahoo.com

Received: November 2, 2020 - Accepted: April 29, 2021 
dismutase (SOD) $(3145,2559,3345 \mu \mathrm{g}-1 \mathrm{FWh}$ - 1), catalase (CAT) (300, 366, $3243 \mu \mathrm{g}$-1FWh-1) e malondialdeído diminuído (MDA) $(6,5,12,2,6,5 \mu \mathrm{mol}$ g-1 FW) para as variedades de arroz Zhongzao 39 e KSK 133 sob baixo $(\mathrm{LT}+\mathrm{NTW})$, temperatura ótima (OP + NTW) e estresse de alta temperatura (HT + NTW). Portanto, o nanopriming é recomendado para lidar com as condições de estresse de alta e baixa temperatura, juntamente com a produtividade aprimorada do arroz.

Palavras-chave: enzimas antioxidantes; temperatura alta, temperatura baixa, priming de sementes.

\section{Introduction}

Rice (Oryza sativa L.) has been nurtured for an immense portion of the realm's populace specifically in Western Asia, the Mid East, and the Caribbean region (FAO, 2005). A huge amount of rice cultivation and consumption occur in Asia specifically in China and Pakistan (Datta and Adhya, 2014). It is cultivated in more than 100 countries which can deliver more than 483 million tons of milled rice every year (Dass et al., 2017). In the future, the demand for rice probably rise due to increase in consumption up to 496 million tons (mt) in 2020, and $555 \mathrm{mt}$ by 2035 (FAO, 2005). Asia is cultivating rice on a vast scale due to excessive field area, and that's why its demand and supply are going smoothly and steadily until now. Expected trade of rice all over the world record in 2022 will be (000 tons) USA 3320 tons, Thailand 11,000 (000 tons), Pakistan 4300 (000 tons), China 1800 (000 tons) (Younas et al., 2020)

The variations in climatic conditions and upsurge in the human population are continuously posing threat to crop production and management practices (Akram, 2007). Climate change now has become the world's most critical issue so, it is necessary to improve the resistance in the agricultural crop against various abiotic stresses (Wang et al., 2016; Scremin-Dias et al., 2011). Climatic change is generally categorized by the present global warming scenario (Fischer et al., 2005; Jerônimo et al., 2011). Therefore, it has become evident that temperature has become the major abiotic stress in the rice cultivation system (Bashir et al. 2007). Low temperature and high temperature are critically impacting rice production and causing more than half of the global yield losses annually (Ribant et al., 2002).

In the modern agricultural system, different approaches are employed to lessen the high and low-temperature effects in crops. Among these approaches, seed priming is an operative, beneficial, cost-effective for improved fast, and even germination (Paparella et al., 2015; Jeller et al., 2003). This technique helps to activate the standard metabolic process during the primary stage of sprouting before the root emergence (Hussain et al., 2015). It can also reduce the longevity duration of germination (Hill et al., 2007). The rice sprouting and other developmental stages might be enriched by seed priming (Farooq et al., 2007a). Qiangdi nano-863 biological assistant growth apparatus is an agricultural high tech invention and most widely used in China (Jun-rong et al., 2016). Farooq et al. (2007b) demonstrated Osmo-hardening with $\mathrm{CaCl}_{2}$ and better sprouting likewise Rehman et al. (2011) testified improved plantlet growth and crop harvest. The suitable amount of Hydrogen peroxide $\left(\mathrm{H}_{2} \mathrm{O}_{2}\right)$ was favorable for breaking seed dormancy and improved growth (Lariguet et al.,
2013). $\mathrm{H}_{2} \mathrm{O}_{2}$ was involved in the improvement of signaling pathways of hormones (SA, GA, and ABA) El MaaroufBouteau et al. (2015). Salicylic acid (SA) was a renounced hormone promoting plant defensive system to biotic and abiotic stress (Yan and Dong, 2014).

Rice is the main food crop and cultivated mostly in colder, tropical, arid, semi-arid, and temperate regions of the world where low and high temperatures are barriers to good rice crop establishment. But few studies have been conducted for temperature based comparable execution of seed priming. The main purpose of current experimentation was to assess the response of various seed priming techniques on the germination of seed under low and high-temperature stress. Moreover, this study also focused to investigate biochemical and physiological characteristics in primed rice seedlings.

\section{Materials and Methods}

\subsection{Plant material and growing conditions}

Five rice varieties Zhongzao 39 (Chinese Indica variety), KSK 133, KS 282, Super Basmati, and PK aromatic 1121 (Pakistani Indica varieties) seed were used as experimental germplasm (Table 1). For removal of contamination in the trail of seed priming, germplasm was superficially treated with $3 \% \mathrm{NaClO}$ solution (domestic bleach diluted 1:1 with distilled water) for 30 minutes and rinsed with sanitized water. The early sprouting of rice seed was $>95-98 \%$ in this study. This trial was carried out at the State key laboratory of Rice Biology, China National Rice Research Institute, Hangzhou in 2017.

\subsection{Experimental design}

For different treatments, nano-synergid treated water was prepared with a variation of the duration of soaking of the disc in water. Qiangdi nano-863 biological assistant growth apparatus (disc) was placed in a plastic bucket with $20 \mathrm{~L}$ water for 72 hours to produce nano-treated water. Rice seed was pre-soaked in tap water for 24 hours, and then soaked in nano-treated water for germination.

In the present study Osmopriming $\left(\mathrm{CaCl}_{2}: 150 \mathrm{mg} / \mathrm{L}\right.$ Calcium chloride), Redox priming $\left(\mathrm{H}_{2} \mathrm{O}_{2}: 50 \mu \mathrm{M}\right.$ Hydrogen peroxide), and Hormonal priming (SA: $150 \mathrm{mg} / \mathrm{L}$ Salicylic acid) methods were utilized. Priming reagents were preoptimized for their significant level established on seed germination and initial seedlings proliferation execution. Seed was primed at $26^{\circ} \mathrm{C}$ for 24 hours through continual moderate agitation (100rpm). The division of seed mass to primed solutions dimensions $(\mathrm{w} / \mathrm{v}$ ) was $1: 5$. The seed was dripping in the preparing solutions for 12 hrs and 24 hrs 
Table 1. List of rice germplasm used in study at China National Rice Research Institute, 2017/18.

\begin{tabular}{llccc}
\hline \multicolumn{1}{c}{ Rice varieties } & \multicolumn{1}{c}{ Parentage/Pedigree } & Year of Release & Breeding Center & Province/Country \\
\hline Zhongzao 39 & Jiayu 253/Zhongzu no.3 & 2012 & CNRRI, Hangzhou & Zhejiang, China \\
KSK 133 & KS 282× 4321 & 2006 & KSK, Lahore & Punjab, Pakistan \\
KS 282 & Basmati 370×IR95 & 1982 & KSK, Lahore & Punjab, Pakistan \\
Super Basmati & Basmati×10486 & 1996 & KSK, Lahore & Punjab, Pakistan \\
PK 1121 aromatic & $\begin{array}{l}\text { Selection from farmer's fields } \\
\text { for extra-long grain and high } \\
\text { elongation ratio }\end{array}$ & 2013 & KSK, Lahore & Punjab, Pakistan \\
& & & & \\
\hline
\end{tabular}

interval. After 24 hrs seed was rinsed by purified water. The seed dried by filter paper and moved to the air-drying oven at $25^{\circ} \mathrm{C}$ for $48 \mathrm{hrs}$. to minimize the moistness.

\subsection{Temperature treatments}

All the five varieties were sown under three different temperatures; low temperature $\left(17^{\circ} \mathrm{C}\right)$, optimum temperature $\left(27^{\circ} \mathrm{C}\right)$ and high temperature $\left(37^{\circ} \mathrm{C}\right)$.

\subsubsection{Low-temperature treatments}

Low-temperature treatments included; Variety 1 (Zhongzao 39), Control + low temperature and No priming (Zhongzao 39+LT +NP), Zhongzao 39, low temperature and Nano treated water priming (Zhongzao 39+LT+NTW), low temperature and Calcium chloride priming (Zhongzao $39+\mathrm{LT}+\mathrm{CaCl}_{2}$ ), Zhongzao 39, low temperature and $\mathrm{H}_{2} \mathrm{O}_{2}$ priming (Zhongzao 39+ LT $+\mathrm{H}_{2} \mathrm{O}_{2}$ ), Zhongzao 39, low temperature and SA priming (Zhongzao 39+ LT+SA).

Variety 2 (KSK 133) Control+ low temperature and No priming (KSK 133+LT +NP), KSK 133, low temperature and Nano treated water priming (KSK 133+LT+NTW), low temperature and Calcium chloride priming (KSK $133+\mathrm{LT}+\mathrm{CaCl}_{2}$ ), KSK 133, low temperature and $\mathrm{H}_{2} \mathrm{O}_{2}$ priming (KSK 133+ LT $+\mathrm{H}_{2} \mathrm{O}_{2}$ ), KSK 133, low temperature and SA priming (KSK 133+ LT+SA).

Variety 3 (KS 282) Control + low temperature and No priming (KS 282+LT +NP), KS 282, low temperature and Nano treated water priming (KS 282+LT+NTW), KS 282, low temperature and Calcium chloride) priming (KS $282+\mathrm{LT}+\mathrm{CaCl}_{2}$ ), $\mathrm{KS} 282$, low temperature and $\mathrm{H}_{2} \mathrm{O}_{2}$ priming ( $\mathrm{KS} 282+\mathrm{LT}+\mathrm{H}_{2} \mathrm{O}_{2}$ ), KS 282, low temperature and SA priming (KS 282+ LT+SA).

Variety 4 (Super Basmati) Control + low temperature and No priming (Super bas +LT +NP), Super bas, low temperature and Nano treated water priming (Super bas +LT+NTW), Super bas, low temperature and Calcium chloride priming (Super bas $+\mathrm{LT}+\mathrm{CaCl}_{2}$ ), Super bas, low temperature and $\mathrm{H}_{2} \mathrm{O}_{2}$ priming (Super bas $+\mathrm{LT}+\mathrm{H}_{2} \mathrm{O}_{2}$ ), Super bas, low temperature and SA priming (Super bas + LT+SA)

Variety 5 (PK 1121 Aromatic) Control + low temperature and No priming (PK 1121 aroma +LT +NP), PK 1121 aroma, low temperature and Nano treated water priming (PK 1121 aroma +LT+NTW), PK 1121 aroma, low temperature and Calcium chloride priming (PK 1121 aroma $+\mathrm{LT}+\mathrm{CaCl}_{2}$ ),
PK 1121 aroma, low temperature and $\mathrm{H}_{2} \mathrm{O}_{2}$ priming (PK 1121 aroma $+\mathrm{LT}+\mathrm{H}_{2} \mathrm{O}_{2}$ ), PK 1121aroma, low temperature and SA priming (PK 1121aroma+ LT+SA).

\subsubsection{Optimum-temperature treatments}

Optimum-temperature treatments included; Variety 1 (Zhongzao 39), Control + Optimum temperature and No priming (Zhongzao 39+OT +NP), Zhongzao 39, Optimum temperature and Nano treated water priming (Zhongzao 39+OT+NTW), Optimum temperature and Calcium chloride priming (Zhongzao 39+OT $+\mathrm{CaCl}_{2}$ ), Zhongzao 39, Optimum temperature and $\mathrm{H}_{2} \mathrm{O}_{2}$ priming (Zhongzao 39+ OT $+\mathrm{H}_{2} \mathrm{O}_{2}$ ), Zhongzao 39, Optimum temperature and SA priming (Zhongzao 39+ OT+SA).

Variety 2 (KSK 133) Control+ Optimum temperature and No priming (KSK 133+OT +NP), KSK 133, Optimum temperature and Nano treated water priming (KSK 133+OT+NTW), Optimum temperature and Calcium chloride priming (KSK 133+OT+CaCl2), KSK 133, Optimum temperature and $\mathrm{H} 2 \mathrm{O} 2$ priming (KSK 133+ OT+H2O2), KSK 133, Optimum temperature and SA priming (KSK $133+$ OT+SA).

Variety 3 (KS 282) Control + Optimum temperature and No priming (KS 282+OT +NP), KS 282, Optimum temperature and Nano treated water priming (KS 282+OT+NTW), KS 282, Optimum temperature and Calcium chloride) priming ( $\mathrm{KS} 282+\mathrm{OT}+\mathrm{CaCl}_{2}$ ), $\mathrm{KS} 282$, Optimum temperature and $\mathrm{H}_{2} \mathrm{O}_{2}$ priming $\left(\mathrm{KS} 282+\mathrm{OT}+\mathrm{H}_{2} \mathrm{O}_{2}\right), \mathrm{KS} 282$, Optimum temperature and SA priming (KS 282+ OT+SA).

Variety 4 (Super Basmati) Control + Optimum temperature and No priming (Super bas +OT +NP), Super bas, Optimum temperature and Nano treated water priming (Super bas+OT+NTW), Super bas, Optimum temperature and Calcium chloride priming (Super bas $+\mathrm{OT}+\mathrm{CaCl}_{2}$ ), Super bas, Optimum temperature and $\mathrm{H}_{2} \mathrm{O}_{2}$ priming (Super bas + OT+H2O2), Super bas, Optimum temperature and SA priming (Super bas + OT+SA)

Variety 5 (PK 1121 Aromatic) Control + Optimum temperature and No priming (PK 1121aroma +OT +NP), PK 1121 aroma, Optimum temperature and Nano treated water priming (PK 1121aroma +OT+NTW), PK 1121 aroma, Optimum temperature and Calcium chloride priming (PK 1121aroma +OT+CaCl 2 ), PK 1121 aroma, Optimum temperature and $\mathrm{H}_{2} \mathrm{O}_{2}$ priming ( $\mathrm{PK} 1121$ aroma $+\mathrm{OT}+\mathrm{H}_{2} \mathrm{O}_{2}$ ), PK 1121aroma, Optimum temperature and SA priming (PK 1121 aroma+ OT+SA). 


\subsubsection{High-temperature treatments}

High-temperature treatments included; Variety 1 (Zhongzao 39), Control + High temperature and No priming (Zhongzao 39+HT +NP), Zhongzao 39, High temperature and Nano treated water priming (Zhongzao 39+HT+NTW), High temperature and Calcium chloride priming (Zhongzao 39+HT+CaCl ), Zhongzao 39, High temperature and $\mathrm{H}_{2} \mathrm{O}_{2}$ priming (Zhongzao 39+ $\mathrm{HT}+\mathrm{H}_{2} \mathrm{O}_{2}$ ), Zhongzao 39, Optimum temperature and SA priming (Zhongzao 39+ HT+SA).

Variety 2 (KSK 133) Control+ Optimum temperature and No priming (KSK 133+OT +NP), KSK 133, Optimum temperature and Nano treated water priming (KSK 133+OT+NTW), Optimum temperature and Calcium chloride priming (KSK 133+OT+CaCl2), KSK 133, Optimum temperature and $\mathrm{H} 2 \mathrm{O} 2$ priming (KSK 133+ OT+H2O2), KSK 133, Optimum temperature and SA priming (KSK 133+ OT+SA).

Variety 3 (KS 282) Control + High temperature and No priming (KS 282+HT +NP), KS 282, High temperature and Nano treated water priming (KS 282+HT+NTW), KS 282, High temperature and Calcium chloride) priming (KS $282+\mathrm{HT}+\mathrm{CaCl}_{2}$ ), $\mathrm{KS} 282$, High temperature and $\mathrm{H}_{2} \mathrm{O}_{2}$ priming (KS 282+ HT+H2O2), KS 282, High temperature and SA priming (KS 282+ HT+SA).

Variety 4 (Super Basmati) Control + High temperature and No priming (Super bas $+\mathrm{HT}+\mathrm{NP}$ ), Super bas, High temperature and Nano treated water priming (Super bas $+\mathrm{HT}+\mathrm{NTW}$ ), Super bas, High temperature and Calcium chloride priming (Super bas $+\mathrm{HT}+\mathrm{CaCl}_{2}$ ), Super bas, High temperature and $\mathrm{H}_{2} \mathrm{O}_{2}$ priming (Super bas $+\mathrm{HT}+\mathrm{H}_{2} \mathrm{O}_{2}$ ), Super bas, High temperature and SA priming (Super bas $+\mathrm{HT}+\mathrm{SA}$ )

Variety 5 (PK 1121 Aromatic) Control + High temperature and No priming (PK 1121 aroma +HT +NP), PK 1121 aroma, High temperature and Nano treated water priming (PK 1121 aroma +HT+NTW), PK 1121 aroma, High temperature and Calcium chloride priming ( $\mathrm{PK} 1121$ aroma $+\mathrm{HT}+\mathrm{CaCl}_{2}$ ), PK 1121 aroma, High temperature and $\mathrm{H}_{2} \mathrm{O}_{2}$ priming ( $\mathrm{PK}$ 1121 aroma $+\mathrm{HT}+\mathrm{H}_{2} \mathrm{O}_{2}$ ), PK 1121 aroma, High temperature and SA priming (PK 1121aroma+ HT+SA).

The abiotic stresses of low temperature and high temperature were applied in growth chambers via controlling the daylight and dark temperatures at $17^{\circ} \mathrm{C}$ and $37^{\circ} \mathrm{C}$. Optimal temperature $\left(27^{\circ} \mathrm{C}\right)$ was maintained in a separate growth chamber for priming technique. All three growth chambers were provided with $12 \mathrm{hrs}$ light period and $60 \%$ humidity at $17^{\circ} \mathrm{C}, 27^{\circ} \mathrm{C}$, and $37^{\circ} \mathrm{C}$.

In all treatments, 30 seeds were placed into each plate. Vigorous seed from each treatment (with three replications) was consistently sprouted in glass plates per/by two layers of filter paper covered through the lid. After adding $10 \mathrm{ml}$ of water to each treatment, Petri plates were placed on the metal shelves in growth chambers. All treatments were arranged in a completely randomized design (CRD) for recording the physiological and biochemical attributes in replicates. The seed were considered to be germinated when the radical was just emerged $(1-2 \mathrm{~cm})$. The germination test was ended when there was no germination till 8 days of sowing. Seedlings were transferred to hydroponic media for observing the physiological and biochemical attributes at the leaf stage (30 days).

\subsection{Germination/seedling development and dry biomass}

Germination was recorded daily by following Association for official seed analysists (AOSA, 1990) until it turned into constant. The speed of germination (SG), germination energy percentage (GE \%), and final germination percent (FGP \%) were estimated by using the following formulae. Dry biomass was weighed by using 10 random rice sprouts. Root and shoot dry weights were documented after oven drying at $70^{\circ} \mathrm{C}$ for one day. The formulae are $S G=($ Number of germinated seed)/(Days of first count) $+\ldots .+$ (Number of germinated seeds)/(Days of final count); GE (\%) = (Number of germinated seed at DAS) / (Total number of seed $\times 100$; $\mathrm{FGP}=(($ Number of final germinated seed $) /($ Total number of seed) $\times 100$

\subsection{Chlorophyll content/mg $\mathrm{g}^{-1} \mathrm{Fw}$}

$0.25 \mathrm{~g}$ of seedling was used for the extraction of Chlorophyll content. The seedling sample was soaked in a $25 \mathrm{ml}$ mixture of acetone and alcohol ratio $\mathrm{v}: \mathrm{v}=1: 1$ for one day in the dark at room temperature. 663, 645, and $470 \mathrm{~nm}$ using UV-2600, Shimadzu, Japan absorbance were used for measurement of chlorophyll a, chlorophyll b and carotenoids contents according to Marschall and Proctor (2004). The equations are $C a=12.7 \times A 663-2.69 \times A 645$; $C b=22.9 \times A 645-4.68 \times A 663$

Content of chlorophyll $=(\mathrm{Ca}+\mathrm{Cb}) \times \mathrm{Va} / \mathrm{m}$ leaf 6

\subsection{Antioxidant enzymes activities}

\subsubsection{Catalase (CAT) $\mu \mathrm{g}^{-1} \mathrm{FW} \mathrm{h} \mathrm{h}^{-1}$ and Superoxide Dismutase (SOD) $\mu g^{-1} \mathrm{FW} \mathrm{h}^{-1}$}

For CAT activity, the reaction mixture containing $50 \mathrm{mmol}$ sodium phosphate buffer ( $\mathrm{pH} 7.0$ ), $20 \mathrm{mmol} \mathrm{H}_{2} \mathrm{O}_{2}$. and $0.04 \mathrm{ml}$ of extracted rice sample. This absorbance was measured at $240 \mathrm{~nm}$ for 300 seconds. One unit of CAT was defined as the amount of enzyme required to oxidize $1 \mu \mathrm{mol}$ $\mathrm{H}_{2} \mathrm{O}_{2} \mathrm{~min}^{-1}$. The reaction mixture of SOD contained $25 \mathrm{mmol}$ sodium phosphate buffer ( $\mathrm{pH} 7.8$ ), $13 \mathrm{mmol}$ methionine, $2 \mu \mathrm{mol}$ riboflavin, $10 \mu \mathrm{mol}$ EDTA-Na, $75 \mu \mathrm{mol} \mathrm{NBT}$, and $0.1 \mathrm{ml}$ leaf extract. The total quantity of reaction mixture was $3 \mathrm{ml}$. The test tube containing reaction solutions was irrigated with light (fluorescent lamps $300 \mu \mathrm{mol} \mathrm{m}{ }^{-2} \mathrm{~s}^{-1}$ ) for 20 mins and the activity was measured at $560 \mathrm{~nm}$ wavelength. Determination of catalase and Superoxide Dismutase enzymes was done (Zheng et al., 2016).

\subsubsection{Malondialdehyde (MDA) $\mu \mathrm{mol} \mathrm{g}^{-1} \mathrm{FW}$}

Malondialdehyde was done by the method of Chun and Ren (2003). $2 \mathrm{ml}$ Seedling extract was added in $0.5 \mathrm{ml}$ (v/v) thiobarbituric acid, $1 \mathrm{ml} 20 \%(\mathrm{v} / \mathrm{v})$ trichloroacetic acid. The mixture was heated in a pre-heated water bath at $95^{\circ} \mathrm{C}$ for 20 mins, cooled at room temperature, and centrifuged at 10,000 rpm $\times \mathrm{g}$ for $10 \mathrm{mins}$. 450, 532 and $600 \mathrm{~nm}$ absorbance was used for measurement of lipid peroxidation by UV-VS Spectrophotometer-2600 Shimadzu. Calculation of malondialdehyde done by an extinction coefficient of $155 \mathrm{mM}^{-1} \mathrm{~cm}^{-1}$ and expressed in terms of $\mu \mathrm{mol} \mathrm{g}{ }^{-1} \mathrm{FW}$. 


\subsection{Statistical analysis}

The data of five rice varieties (KSK 133, Zhongzao 39, Super basmati, KS 282, and PK 1121 aromatic) was recorded and subjected to statistical analysis. The analysis was performed by standard analyses of variance (Three-way ANOVA) using the software SPSS v. 20 Zheng et al. (2016). The comparison of mean values was done by using the least significant difference (LSD) test at the 0.05 probability level $(\mathrm{P}<0.05)$.

\section{Results}

\subsection{Priming enhanced seed germination at Low} temperature $\left(17^{\circ} \mathrm{C}\right)$, optimal conditions $\left(27^{\circ} \mathrm{C}\right)$ and high temperature $\left(37^{\circ} \mathrm{C}\right)$

Data on germination was collected on daily basis. The seed primed with NTW, $\mathrm{CaCl}_{2}, \mathrm{H}_{2} \mathrm{O}_{2}$, and SA showed variations in germination rate under low, optimum, and high-temperature conditions. But the most significant results were showed in nano-priming. The germination energy percentage, speed of germination and final germination percentage significantly increased in NTW primed seed at all temperatures.

At LT+NTW, OT+NTW and HT+NTW the percentage germination of five rice varieties Zhongzao 39, KSK 133, KS 282 and Super basmati and PK1121 aromatic (98.4\%, 99.4\%, 98.78\%, 98.8\% and 78\% respectively) was recorded, at high temperature (Table 2). At all temperatures, $\mathrm{H}_{2} \mathrm{O}_{2}$ and $\mathrm{Cacl}_{2}$ showed improved germination but less than nanopriming. However, $\mathrm{LT}+\mathrm{SA}, \mathrm{OT}+\mathrm{SA}$ and $\mathrm{HT}+\mathrm{SA}$ showed least significant improvement in germination. Three-way ANOVA for collected data indicated that the interaction between all five varieties, three temperatures, and four priming agents was significant (Table 3 ).

\subsection{Seed priming elevated dry weight at low temperature $\left(17^{\circ} \mathrm{C}\right)$, optimal $\left(27^{\circ} \mathrm{C}\right)$ and high temperature $\left(37^{\circ} \mathrm{C}\right)$ conditions}

Under the influence of LT+NTW treatment, dry weight of Zhongzao 39 and KSK 133 (0.11 and 0.12g respectively) exhibited the highest and Aromatic PK 1121 lowest (0.01g) biomass. All varieties showed improved biomass production with $\mathrm{LT}+\mathrm{H}_{2} \mathrm{O}_{2}$ and $\mathrm{LT}+\mathrm{CaCl}_{2}$ treatment but lesser than NTW treatment (Figure 1A). However, KSK 133+OT+NTW and KS 282+OT+NTW depicted an increase in dry weight (0.14 and $0.13 \mathrm{~g}$ respectively) at treatment conditions (Figure $1 \mathrm{~B}$ ). As compared to control, Zhongzao $39+\mathrm{HT}+\mathrm{NTW}$ and KS $282+\mathrm{HT}+\mathrm{NTW}$ were exhibited significantly higher biomass (Figure 1C). These two treatments KSK $133+\mathrm{HT}+\mathrm{H}_{2} \mathrm{O}_{2}$ and $\mathrm{KS} 282+\mathrm{HT}+\mathrm{H}_{2} \mathrm{O}_{2}$ were statistically similar $(\mathrm{P}<0.05)$ with each other in dry biomass evaluation (Figure 1C). Three-way ANOVA for biomass data indicated that dependent factor dry biomass with five rice varieties, three temperatures, and four priming agents displayed significant results (Table 3 ).

\subsection{Seed priming improved the accumulation of} chlorophyll content at low $\left(17^{\circ} \mathrm{C}\right)$, optimal $\left(27^{\circ} \mathrm{C}\right)$, and high temperature $\left(37^{\circ} \mathrm{C}\right)$ conditions

All priming agents considerably increased the chlorophyll content in all five varieties under low, optimal, and high-temperature conditions (Table 4). The KSK 133+LT+NTW treatment led to enhanced chlorophyll contents (up to $0.201 \mathrm{mg} / \mathrm{g}$ FW). Whereas, chlorophyll contents of Zhongzao 39, KS 282 and PK 1121 aromatic were moderate $(0.132$, and $0.094 \mathrm{mg} / \mathrm{g}$ FW), and Super Basmati $(0.068 \mathrm{mg} / \mathrm{g} \mathrm{FW})$ showed the least improvement at LT+NTW (Table 4). At OT+NTW all five rice varieties showed improved chlorophyll content than OT+ NP. Zhongzao 39+OT+NTW and KSK 133+OT+NTW showed 13.74 and $23.86 \mathrm{mg} / \mathrm{g}$ FW, respectively had elevated chlorophyll content than other rice varieties (Table 3 ).

Compared with NP+HT, chlorophyll contents promoted in KSK 133+HT+NTW (22.01 mg/g FW), KS 282+HT+NTW (17.77 mg/g FW) however, the least improvement was observed in super basmati+HT+CaCl $(3.587 \mathrm{mg} / \mathrm{g} \mathrm{FW})$ (Table 4). Three-way ANOVA for chlorophyll content data for all treatment indicated that all five varieties of three temperatures and four priming agents had significant interaction.

\subsection{Seed priming enhanced the oxidative enzyme catalase} (CAT) and Superoxide dismutase (SOD) activity at lowtemperature $17^{\circ} \mathrm{C}$ optimal $\left(27^{\circ} \mathrm{C}\right)$ and high temperature $\left(37^{\circ} \mathrm{C}\right)$ conditions

Data regarding oxidative enzyme CAT and SOD increased at LT, OT, and HT rice seedlings with priming agents. CAT and SOD enzymes of five rice varieties revealed significant improvement at LT+NTW (Figure 2A, 2D). All five varieties exhibited the highest catalase activity at LT+NTW treatment and least CAT improved at LT+SA treatment (Figure 2A). Compared with OT+NP, Zhongzao 39 and KSK 133 showed exhibited maximum improvement in CAT and SOD activities at $\mathrm{OT}+\mathrm{CaCl}_{2}$. At optimal temperature PK 1121 aromatic +OT + NTW, KS 282+OT +NTW, and KSK 133+OT + NTW treatments expressed a higher quantity of CAT and SOD (Figure 2B, 2E).

It was important to note, in Zhongzao 39, KSK 133, KS 282, and PK 1121 aromatic CAT and SOD activities were significantly improved with HT+NTW treatment. The most pronounced enhancement was observed in KSK 133 (CAT $3243 \mathrm{H}_{2} \mathrm{O}_{2} / \mu \mathrm{g}-{ }^{1} \mathrm{FW}$. min and SOD $3345 \mu \mathrm{g}^{-1} \mathrm{FW}$ h-1), with HT+NTW treatment (Figure 2C, 2F). Three-way ANOVA indicated that, dependent factor antioxidant enzymes showed a significant interaction between all five varieties, three different temperatures, and four priming agents (Table 3).

\subsection{MDA content declined by seed priming at low} temperature $\left(17^{\circ} \mathrm{C}\right)$, optimal $\left(27^{\circ} \mathrm{C}\right)$ and high temperature $\left(37^{\circ} \mathrm{C}\right)$ conditions

Lipid peroxidation causes a decrease in the growth and destruction of the plant. Therefore, the current study was deal with lipid peroxidation in the form of MDA content. It was observed that MDA contents were amplified in $\mathrm{NP}+\mathrm{LT}$. As compared to control LT+NTW minimum MDA content was recorded in all rice varieties (Figure 3A). In NP + OT displayed higher lipid peroxidation than NTW treatment. In OT+NTW treatments shown lower MDA contents in all rice varieties. MDA content decreased as the chlorophyll content and oxidative enzyme production 


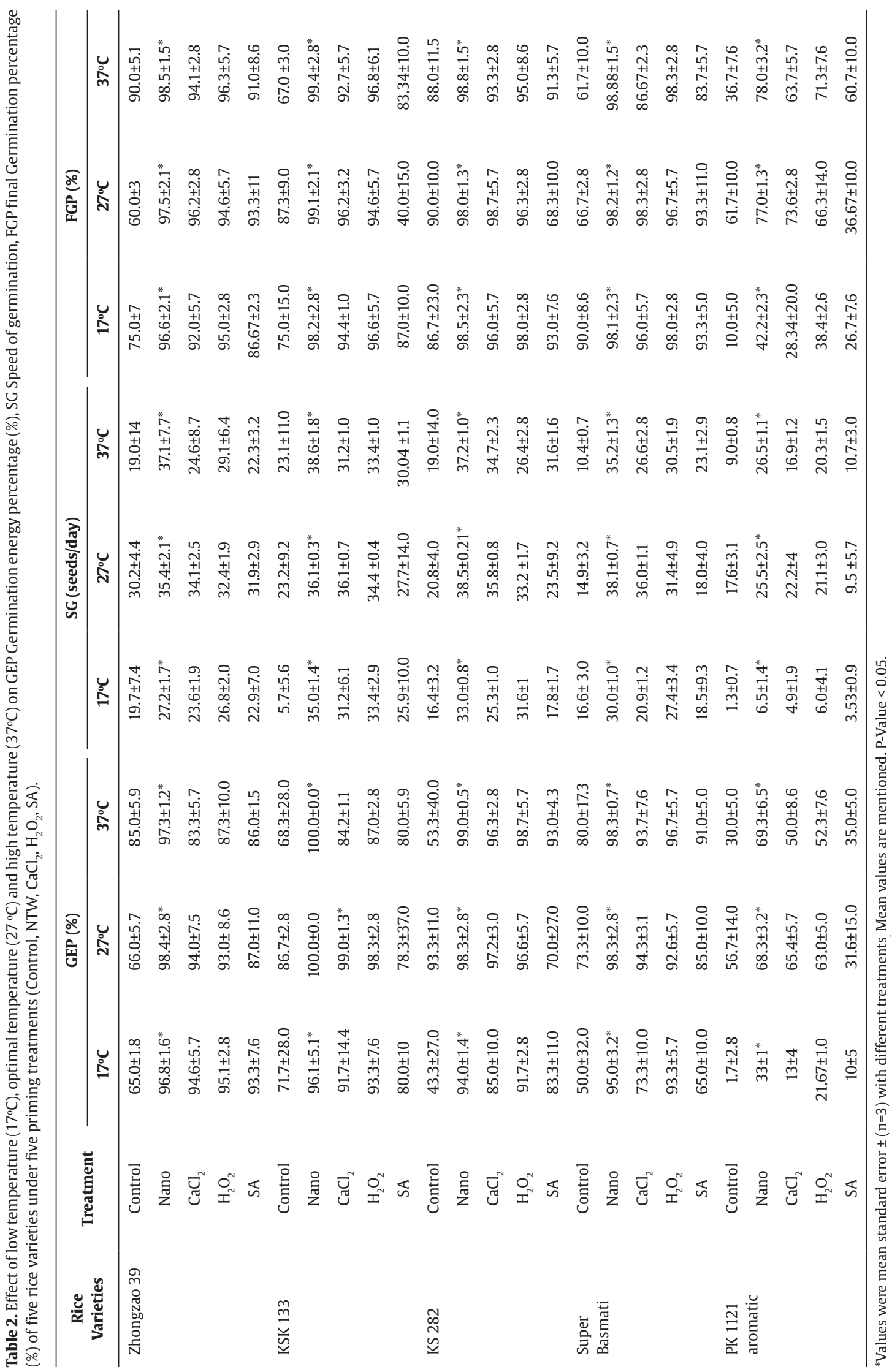


Table 3. Three way ANOVA, analysis of dependent variables (germination, chlorophyll content, dry weight, anti-oxidant enzyme CAT, SOD and MDA).

\begin{tabular}{|c|c|c|c|c|c|c|}
\hline \multirow{2}{*}{ Treatments } & \multicolumn{3}{|c|}{ Germination } & \multicolumn{3}{|c|}{ Chlorophyll } \\
\hline & DF & F-Value & P-Value & DF & F-Value & P-Value \\
\hline Variety & 4 & 6715 & *** & 4 & 27.00 & *** \\
\hline Temperature & 2 & 117 & *** & 2 & 270.00 & *** \\
\hline Priming & 4 & 2052 & $* * *$ & 4 & 5.05 & *** \\
\hline Variety*temperature & 8 & 358 & $* * *$ & 8 & 7.08 & *** \\
\hline Variety*priming agent & 12 & 273 & $* * *$ & 12 & 4.47 & $* * *$ \\
\hline Temperature* priming agent & 6 & 456 & $* * *$ & 6 & 5.46 & $* * *$ \\
\hline Variety*temperature* priming agent & 24 & 227 & $* * *$ & 24 & 1.53 & $* *$ \\
\hline \multirow{2}{*}{ Treatments } & \multicolumn{3}{|c|}{ DW } & \multicolumn{3}{|c|}{ CAT } \\
\hline & DF & F-Value & P-Value & DF & F-Value & P-Value \\
\hline Variety & 4 & 6.28 & $* * *$ & 4 & 0.524 & Non-sig \\
\hline Temperature & 1 & 28.8 & $* * *$ & 2 & 32.70 & $* * *$ \\
\hline Priming & 4 & 1.508 & Non-sig & 4 & 3.04 & $* *$ \\
\hline Variety*temperature & 4 & 10.46 & *** & 7 & 0.40 & Non-sig \\
\hline Variety*priming agent & 12 & 0.758 & Non-sig & 12 & 1.48 & Non-sig \\
\hline Temperature* priming agent & 3 & 0.603 & Non-sig & 6 & 2.86 & $* *$ \\
\hline Variety*temperature*priming agent & 12 & 2.537 & $* * *$ & 19 & 1.73 & $* *$ \\
\hline \multirow{2}{*}{ Treatments } & \multicolumn{3}{|c|}{ SOD } & \multicolumn{3}{|c|}{ MDA } \\
\hline & DF & F-Value & P-Value & DF & F-Value & P-Value \\
\hline Variety & 4 & 2.605 & $* *$ & 4 & 4.01 & *** \\
\hline Temperature & 2 & 7.021 & Non-sig & 2 & 7.70 & *** \\
\hline Priming & 4 & 5.57 & ** & 4 & 14.70 & *** \\
\hline Variety*temperature & 8 & 1.86 & Non-sig & 8 & 10.12 & *** \\
\hline Variety* priming agent & 12 & 1.46 & Non-sig & 12 & 4.33 & *** \\
\hline Temperature* priming agent & 6 & 2.11 & ** & 6 & 3.47 & *** \\
\hline Variety*temperature*priming agent & 24 & 1.31 & $* *$ & 24 & 3.47 & $* * *$ \\
\hline
\end{tabular}

Asterick showed ${ }^{* * *}$ highly significant, ${ }^{* *}$ significant. ${ }^{*}$ Relationship between variety and temperature, DF degree of freedom, DW dry weight, SOD Superoxide Dismutase, CAT Catalase, MDA Malondialdehyde

increased (Figure 3B). In two varieties Zhongzao 39 and KSK133 expressed reduced MDA (6.2 and $6.5 \mathrm{nmol} \mathrm{g-}^{-1} \mathrm{FW}$ ) at $\mathrm{HT}+\mathrm{NTW}$. In all five varieties significantly lessen MDA content with $\mathrm{HT}+\mathrm{NTW}$ treatment conditions than control. (Fig, 3C). Three-way ANOVA disclosed that dependent factor MDA content (Malondialdehyde), exhibited significant interaction between varieties, temperatures, and priming agents (Table 3).

\section{Discussion}

Temperature stress is one of the abiotic stresses limiting growth in cash crop fields. Rice is the major food of more than half of the world's population. So, our main focus on evitable targets to tackle future environmental change on rice production. Therefore, the present study was based on the comparative proficiency of nano, chemical, osmo and hormonal priming at low, optimal, and high temperatures with hydroponic conditions. In current study nano-priming showed most persistent results in all three temperatures. This was the first study scoping all the four types of priming and three different temperatures to take comprehensive results regarding improvement in seed germination, rate of germination, rate of photosynthesis, chlorophyll content.

In recent study found that seed priming treatments led better sprouting and seedling dry weight than control under low-temperature conditions (Table 2, Figure 1A). The previous study has documented seed priming made easy availability of metabolites for germination at low temperature (Hussain et al., 2016). In earlier studies Acharya et al. (2020), demonstrated seed priming with $\mathrm{AgNO}_{3}$ nanoparticles improved germination, chlorophyll, growth and yield of watermelon (Citrullus lanatus). It is 

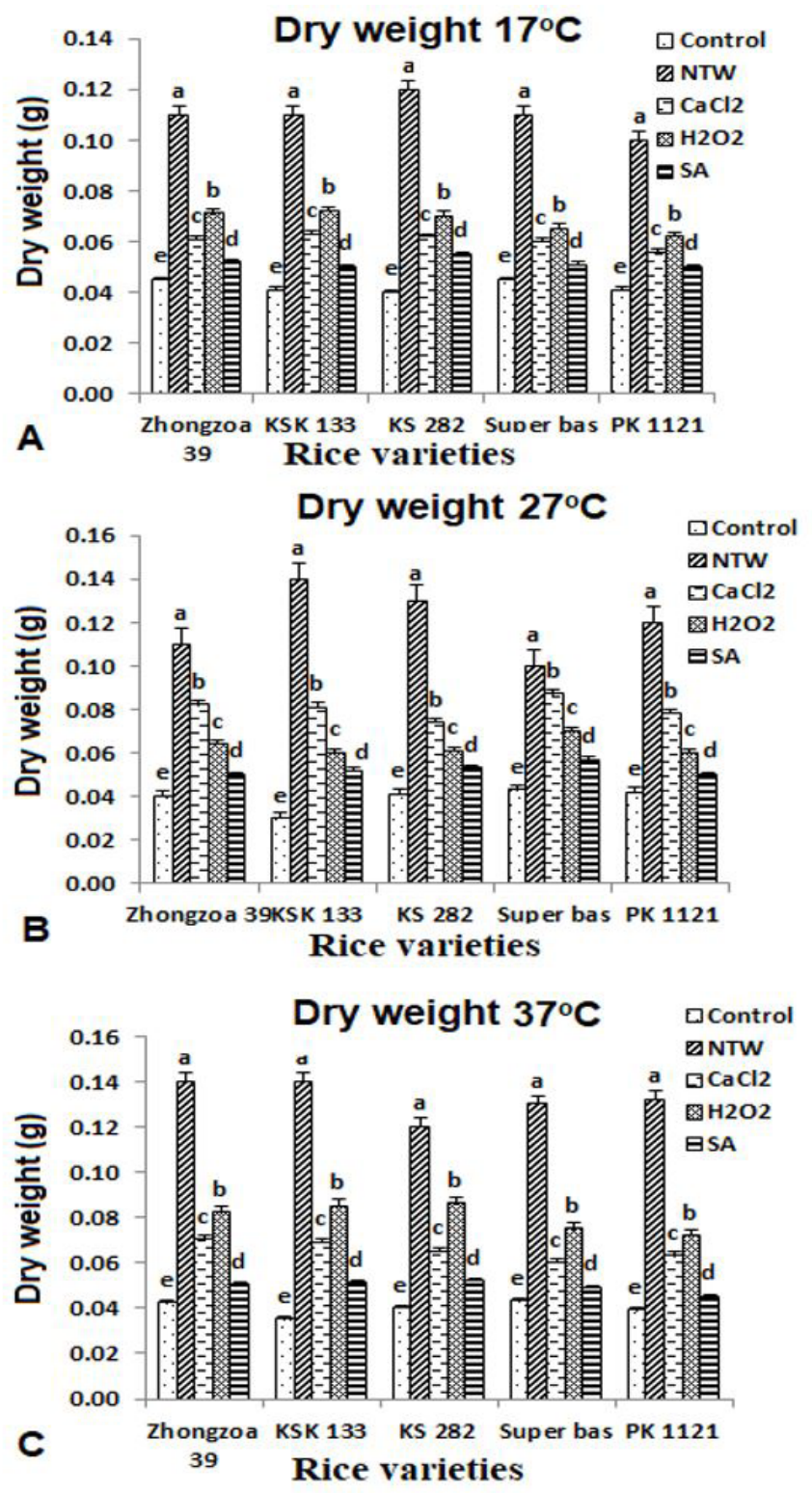

Figure 1. Influence of seed priming on (A) Dry weight at low temperature $17^{\circ} \mathrm{C}$, (B) optimal temperature $27^{\circ} \mathrm{C}$, (C) high temperature $37^{\circ} \mathrm{C}$ of five varieties of rice under five priming treatments (Control, NTW, $\mathrm{CaCl}_{2}, \mathrm{H}_{2} \mathrm{O}_{2}, \mathrm{SA}$ ). Vertical bars above mean indicate standard errors of three replicates.

confirmed from the present study that primed seed had increased germination, chlorophyll content, growth than LT+NP (Table 3). The nano-priming improved the chlorophyll content in Oryza sativa at low temperature (Table 4). Seed priming increased the chlorophyll content, rate of photosynthesis, improved biomass and yield was advocated by Mohajeri et al., 2017.

In OT+NTW treatments were significantly enhanced germination of Oryza sativa. (Table 2) was observed. The current study highlighted considerably rate of photosynthesis, chlorophyll content, biomass, and oxidative enzymes (Table 4) (Figure 1B, Figure 2B, E) under optimum temperature Mohajeri et al. (2017) advocated same observation in the primed seed of beans.

In recent study OT $+\mathrm{CaCl}_{2}$ exhibited enhanced seed germination but less than nano-priming. According to Ruan et al. (2002a, b) that osmopriming with $\mathrm{CaCl}_{2}$ showed a better germination rate and reduced the germination time. $\mathrm{CaCl}_{2}$ is highly soluble in water at ordinary temperatures, but crystallization will occur under certain temperature and concentration conditions (Song et al., 2011). So, present study didn't show worthy results at low and high temperature. 
Table 4. Effect of low temperature $\left(17^{\circ} \mathrm{C}\right)$ Optimal $\left(27^{\circ} \mathrm{C}\right)$ and high temperature $\left(37^{\circ} \mathrm{C}\right)$ on Chlorophyll a, chlorophyll b and total chlorophyll content of five rice varieties under five priming treatments (Control, NTW, $\mathrm{CaCl}_{2}, \mathrm{H}_{2} \mathrm{O}_{2}, \mathrm{SA}$ ).

\begin{tabular}{|c|c|c|c|c|c|c|c|c|c|c|}
\hline \multirow{2}{*}{$\begin{array}{c}\text { Rice } \\
\text { varieties }\end{array}$} & \multirow{2}{*}{ Treatment } & \multicolumn{3}{|c|}{ Chlorophyll a } & \multicolumn{3}{|c|}{ Chlorophyll b } & \multicolumn{3}{|c|}{ Total chlorophyll } \\
\hline & & $17^{\circ} \mathrm{C}$ & $27^{\circ} \mathrm{C}$ & $37^{\circ} \mathrm{C}$ & $17^{\circ} \mathrm{C}$ & $27^{\circ} \mathrm{C}$ & $37^{\circ} \mathrm{C}$ & $1^{\circ} \mathrm{C}$ & $27^{\circ} \mathrm{C}$ & $37^{\circ} \mathrm{C}$ \\
\hline \multirow{5}{*}{$\begin{array}{l}\text { Zhongzao } \\
39\end{array}$} & Control & 0.02 & 1.62 & 8.04 & 0.04 & 0.52 & 2.34 & 0.06 & 2.14 & 10.38 \\
\hline & Nano & $0.20^{*}$ & $8.81^{*}$ & $11.41^{*}$ & $0.30^{*}$ & $4.93^{*}$ & $3.80^{*}$ & $0.50^{*}$ & $13.74^{*}$ & $15.21^{*}$ \\
\hline & $\mathrm{CaCl}_{2}$ & 0.10 & 8.22 & 9.25 & 0.16 & 2.76 & 3.50 & 0.26 & 10.98 & 12.75 \\
\hline & $\mathrm{H}_{2} \mathrm{O}_{2}$ & 0.15 & 2.90 & 10.14 & 0.27 & 1.03 & 3.19 & 0.42 & 3.94 & 13.33 \\
\hline & SA & 0.07 & 0.47 & 7.06 & 0.04 & 0.27 & 3.92 & 0.11 & 0.88 & 10.97 \\
\hline \multirow[t]{5}{*}{ KSK 133} & Control & 0.04 & 1.07 & 3.25 & 9.15 & 0.42 & 0.99 & 9.19 & 1.49 & 4.24 \\
\hline & Nano & $0.13^{*}$ & $8.93^{*}$ & $15.00^{*}$ & $20.10^{*}$ & $3.21^{*}$ & $4.50^{*}$ & $24.01^{*}$ & $23.86^{*}$ & $22.01^{*}$ \\
\hline & $\mathrm{CaCl}_{2}$ & 0.08 & 8.45 & 8.37 & 17.93 & 3.01 & 2.36 & 23.1 & 11.47 & 10.73 \\
\hline & $\mathrm{H}_{2} \mathrm{O}_{2}$ & 0.11 & 6.53 & 14.64 & 15.60 & 2.41 & 4.31 & 23.71 & 8.94 & 18.95 \\
\hline & SA & 0.06 & 3.26 & 7.46 & 9.76 & 1.54 & 2.07 & 10.81 & 4.80 & 9.53 \\
\hline \multirow[t]{5}{*}{ KS 282} & Control & 0.01 & 1.62 & 8.04 & 0.02 & 0.22 & 2.34 & 0.03 & 1.83 & 10.38 \\
\hline & Nano & $0.09^{*}$ & $10.32^{*}$ & $13.52^{*}$ & $0.048^{*}$ & $2.94^{*}$ & $4.53^{*}$ & $0.14^{*}$ & $13.65^{*}$ & $17.77^{*}$ \\
\hline & $\mathrm{CaCl}_{2}$ & 0.04 & 8.22 & 12.24 & 0.04 & 1.04 & 3.24 & 0.08 & 9.26 & 15.48 \\
\hline & $\mathrm{H}_{2} \mathrm{O}_{2}$ & 0.08 & 9.90 & 13.15 & 0.04 & 2.73 & 4.30 & 0.13 & 12.6 & 17.45 \\
\hline & SA & 0.02 & 0.47 & 10.05 & 0.03 & 0.54 & 2.87 & 0.05 & 1.01 & 12.92 \\
\hline \multirow{5}{*}{$\begin{array}{l}\text { Super } \\
\text { Basmati }\end{array}$} & Control & 0.03 & 0.68 & 2.26 & 0.05 & 0.23 & 0.62 & 0.08 & 0.91 & 2.89 \\
\hline & Nano & $0.07^{*}$ & $4.42^{*}$ & $9.11^{*}$ & $0.12^{*}$ & $2.54^{*}$ & $2.88^{*}$ & $0.19^{*}$ & 7.00* & $11.98^{*}$ \\
\hline & $\mathrm{CaCl}_{2}$ & 0.06 & 4.21 & 2.44 & 0.06 & 2.33 & 1.15 & 0.12 & 6.54 & 3.59 \\
\hline & $\mathrm{H}_{2} \mathrm{O}_{2}$ & 0.06 & 3.56 & 8.86 & 0.07 & 2.24 & 2.53 & 0.13 & 5.79 & 11.39 \\
\hline & SA & 0.04 & 1.13 & 6.46 & 0.059 & 0.79 & 1.80 & 0.10 & 1.92 & 8.27 \\
\hline \multirow{5}{*}{$\begin{array}{l}\text { PK } 1121 \\
\text { aromatic }\end{array}$} & Control & 0.01 & 0.04 & 0.10 & 0.01 & 0.65 & 1.73 & 0.02 & 0.69 & 1.83 \\
\hline & Nano & $0.05^{*}$ & $1.95^{*}$ & $10.64^{*}$ & $0.10^{*}$ & $1.12^{*}$ & $5.01^{*}$ & $0.15^{*}$ & $3.10^{*}$ & $15.65^{*}$ \\
\hline & $\mathrm{CaCl}_{2}$ & 0.04 & 1.44 & 10.07 & 0.06 & 1.25 & 4.76 & 0.09 & 2.69 & 14.83 \\
\hline & $\mathrm{H}_{2} \mathrm{O}_{2}$ & 0.04 & 1.76 & 6.33 & 0.08 & 1.10 & 3.87 & 0.13 & 2.87 & 10.20 \\
\hline & SA & 0.035 & 1.39 & 4.71 & 0.04 & 0.05 & 2.77 & 0.08 & 1.45 & 7.47 \\
\hline
\end{tabular}

${ }^{*}$ Mean values are mentioned. P-Value $<0.05$.

Exposure of high temperature in field conditions gave rise to weaken and un-even germination in addition to deprived plantlet formation (Lal et al., 2018). Zheng et al. (2016) verified that seed priming significantly improved the development of seedling and its growth performance under poor water environments. In our results showed that $\mathrm{HT}+\mathrm{H}_{2} \mathrm{O}_{2}$ improved germination and dry biomass but less than NTW+HT treatment conditions. $\mathrm{H}_{2} \mathrm{O}_{2}$ at appropriate concentration helpful for seed dormancy broken and germination improvement but the accumulation of $\mathrm{H}_{2} \mathrm{O}_{2}$ simply caused cell injury (Jeevan Kumar et al., 2015). In the current study, eminent dry weight biomass achieved at NTW+HT (Figure 1C). In KSK 133 and KS 282 varieties pronounced increase in chlorophyll content with NTW priming treatments at high temperature (Table 4) was observed. Literature showed that severe high-temperature stress resulted in incomplete seedling emergence. The seed priming improved the germination rate but less than optimal conditions were concluded by Wahid et al. (2007).

In current study nano-treated water was showed effective results in biochemical components like antioxidant enzymes, reactive oxygen species (ROS), protein, starch, and amino acid. In earlier studies, the effect of priming on antioxidant capacity was found to be correlated with increased transcription (mRNA) levels of enzymatic antioxidants (Christou et al., 2014). In the current study antioxidative enzymes (CAT, SOD) improved in primed seed than NP + LT (Figure $2 \mathrm{~A}, \mathrm{D}$ ). In previous studies, antioxidant enzymes were relatively higher in nano primed seed and more applicable for ROS (Mahakham et al., 2017).

SOD reflects the main role of catalyzing the dismutation of superoxide, whereas CAT pays in scavenging of $\mathrm{H}_{2} \mathrm{O}_{2}$ (Fahad et al., 2015; Borges et al., 2018). The results revealed that oxidative enzymes CAT and SOD increased at LT with NTW (Figure 2A, D). Seed priming enhanced 

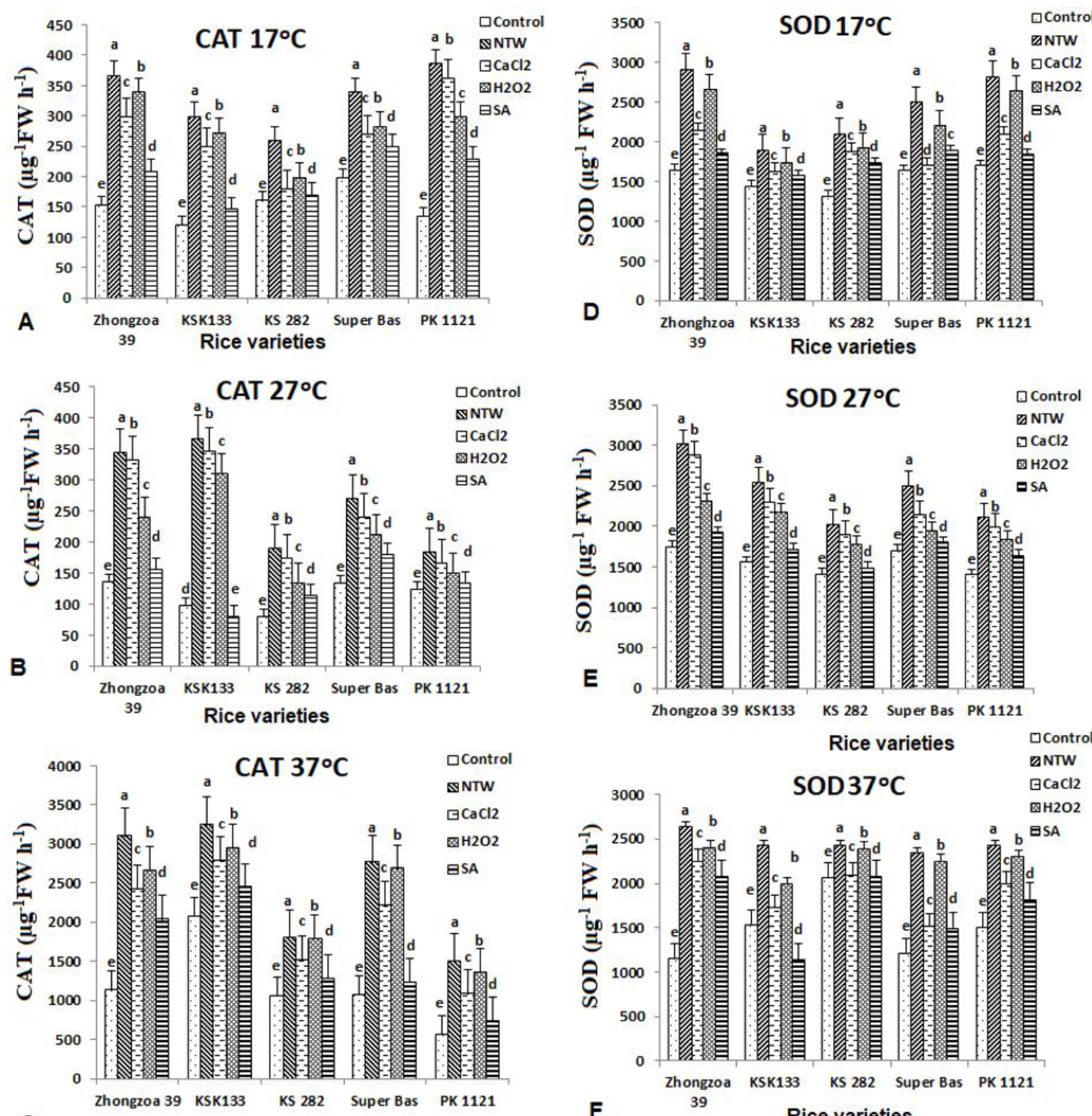

Rice varieties

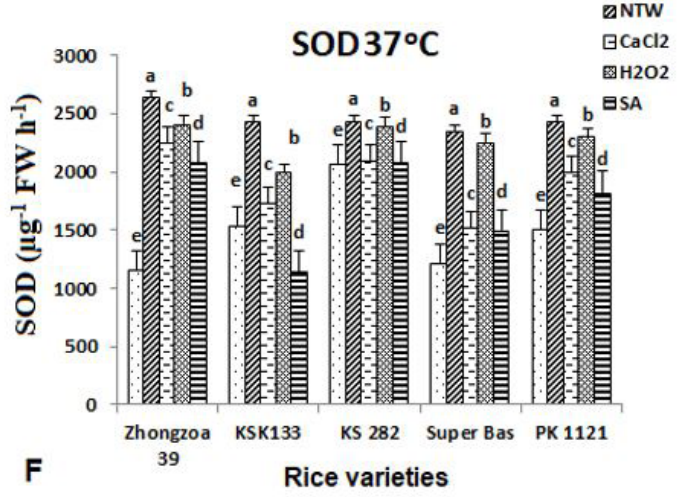

Figure 2. Influence of seed priming on (A) Oxidative enzyme Catalase (CAT) at low temperature $17^{\circ} \mathrm{C},(\mathrm{B})(\mathrm{CAT})$ optimal temperature $27^{\circ} \mathrm{C}$, (C) (CAT) high temperature $37^{\circ} \mathrm{C}$ (D) Oxidative enzyme Superoxide dismutase (SOD) at low temperature $17^{\circ} \mathrm{C}$, (E) (SOD) optimal temperature $27^{\circ} \mathrm{C},(\mathrm{F})(\mathrm{SOD})$ high temperature $37^{\circ} \mathrm{C}$. Vertical bars above mean indicate standard errors of three replicates.

CAT and SOD activities of rice observed in this research is supported by Hussain et al. (2016). The current study highlighted considerably increased rate of photosynthesis, chlorophyll content, biomass, and oxidative enzymes (Table 4) (Figures 1B, 2B, E) under optimum temperature. The oxidative enzymes CAT and SOD improved in redox and Osmopriming but less than nano-priming (Figure 2B, E). Osmo-priming induced increases in antioxidative enzymes (CAT and SOD) activities of rice seedlings have been reported by Wojtyla et al. (2016). The recent investigation confirmed that nano-seed priming under high-temperature conditions effectively enhanced the germination, biomass, chlorophyll content, and antioxidant enzymatic activities (Table 2, 4, Figure 2C, F). In earlier reports recommended that primed seeds showed robust antioxidant system than non-primed seed germination, early seedling growth and enhanced antioxidant enzymes in primed seed can improve seedling growth (Zheng et al., 2016).

MDA is responsible for the synthesis of lipids which possibly decrease carbohydrate content in seed resulted in poor germination. Low temperature enhanced MDA content accumulation in control treatment in all rice varieties (Figure 3A). Previously, an optimistic approach of seed priming in preventing the MDA content and ROS 


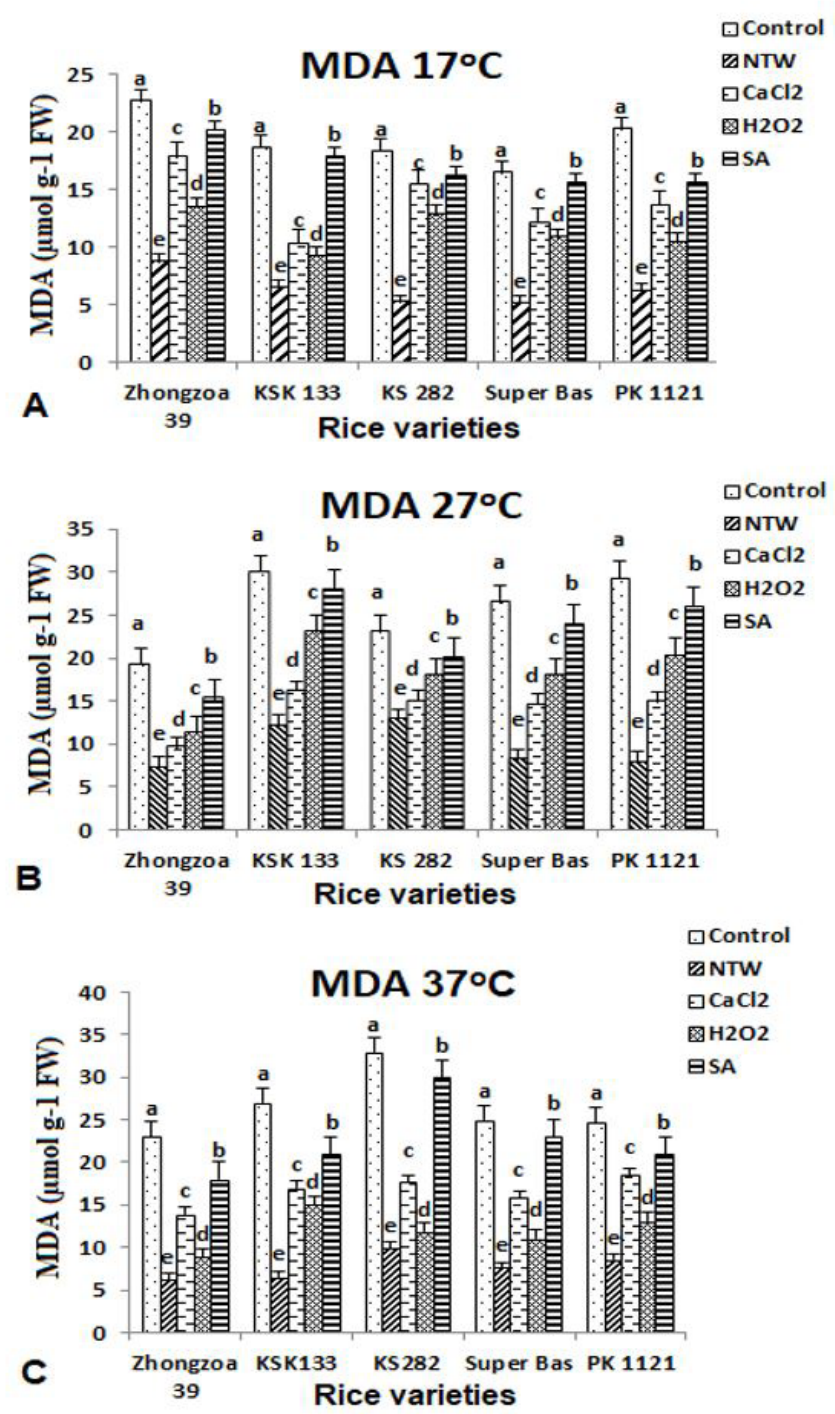

Figure 3. Influence of seed priming on (A) MDA content at low temperature $17^{\circ} \mathrm{C}$, (B) Optimal temperature $27^{\circ} \mathrm{C}$, (C) High temperature $37^{\circ} \mathrm{C}$ of five varieties of rice under five priming treatments (Control, NTW, $\mathrm{CaCl}_{2}, \mathrm{H}_{2} \mathrm{O}_{2}, \mathrm{SA}$ ).

generation was observed for rice (Jisha and Puthur, 2016) seedlings. Similarly, in the current study, all the primed seed significantly lower the MDA under LT. The results from the current study revealed that LT+NTW were most efficient under low temperature than all other seed priming treatments in five rice varieties.

Moreover, a decrease was noticed for MDA contents in primed seed under drought stress (Figure 3C). Consequently, dropping of ROS concentrations and lipid peroxidation may be the main reason in high-temperature tolerance achieved by plantlets of primed seeds (Gill and Tuteja, 2010). Present study results revealed that hormonal priming exhibited lower MDA content in all rice varieties. In previous studies, it was noticed that salicyicate cooperated with other hormonal pathways which caused an increase in resistance of seedling osmotic stress (Ding and Wang, 2003).

\section{Mechanism of Action for Nano-treatments}

Nano electromagnetic waves entered through seed coat into nanoprimed seeds and initiate molecular events for germination. These waves trigger the $\alpha$-amylase activity to convert starch into sugar. This converted sugar provides energy for young dormant embryo to initiate growth. Previous studies reported that nanopriming involves rapid starch degradation as indication of $\alpha$-amylase activity (Mahakham et al., 2017). The initiation of biosynthesis of $\alpha$-amylase is dependent on the activity of Gibberellic acid $\left(\mathrm{GA}_{3}\right)$. It showed there is direct proportional relation between $\mathrm{GA}_{3}$ activity and $\alpha$-amylase synthesis (Figure 4 ). Moreover aquaporin's promotes $\mathrm{GA}_{3}$ production and suppress abscisic acid synthesis. A signaling crosstalk pathway existing between nano waves, $\alpha$-amylase and 


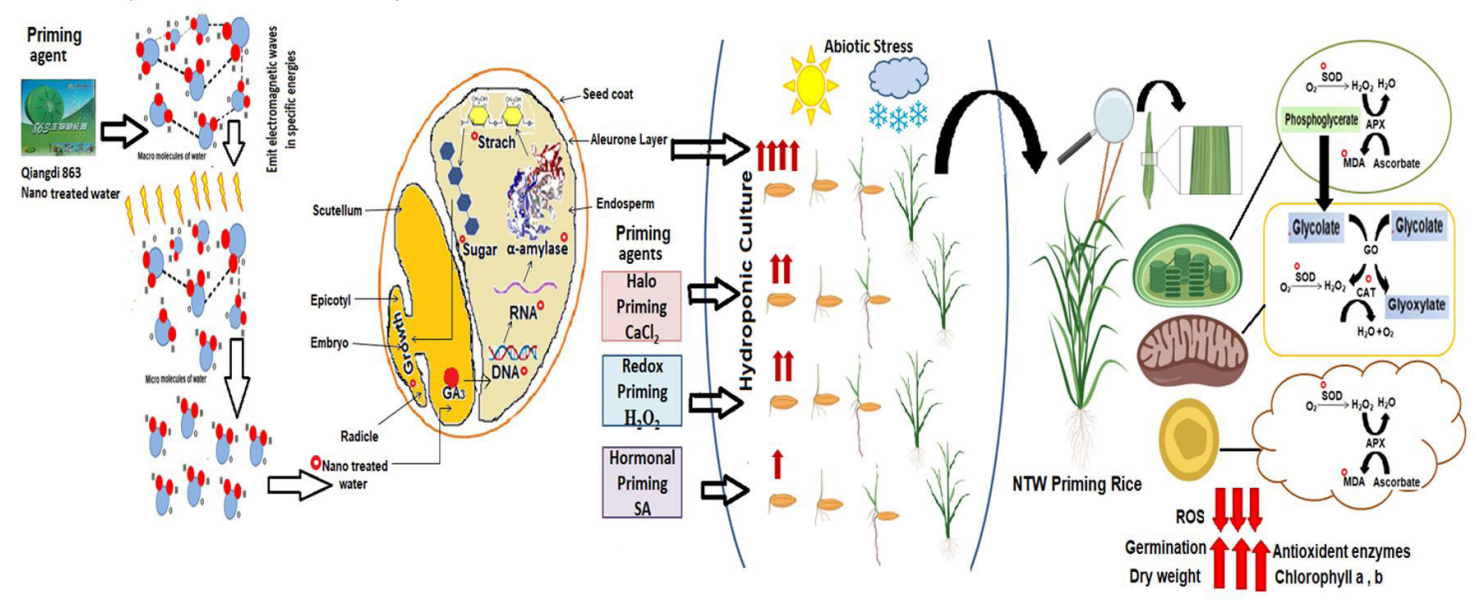

Figure 4. Proposed mechanism of Qiangdi nano-863 treated water induced seed germination physiological and biochemical attributes ofrice. Qiangdi nano-863 emits electromagnetic waves, can declustered water molecules (super-critical water) which increase reaction rates, hydration and solubility of kinetically stable water molecules. Seed priming with nano treated water can enhance seed germination by influx of nano-treated water into seed trigger the expression of genes. Due to activation of genes antioxidant enzyme system (CAT, SOD and MDA) maintain the ROS in optimum range and oxidative systems act as signaling the plant organelles for triggering essential metabolic activity of rice seedling development (germination, dry weight and chlorophyll content.) and growth.

phytohormones in nanoprimed seeds. Previously, reported studies about an association between nanoparticles bond, photochromic had impact on seed germination in a nanoprimed seed (Chandrasekaran et al., 2020). Antioxidant enzymes (e.g. CAT, SOD) act as scavenging system that tightly regulates ROS concentration and enables them to act as cellular messengers. The accumulation of ROS e.g. hydrogen peroxide $\left(\mathrm{H}_{2} \mathrm{O}_{2}\right)$, hydroxyl radicals $(\mathrm{OH})$ and superoxide radicals $\left(\mathrm{O}_{2}\right)$, enhanced the dynamics of seed germination in rice seed. Regulatory proteins of ROS, phytohormones complex along with antioxidant scavengers involved in transduction of ROS signaling cascade. Physiological and biochemical reactions studies may improve more understanding about regulatory role of nanopriming in initiation of seed germination under severe environmental stress conditions.

\section{Conclusion}

Conclusively, exposure of low and high temperature at $17^{\circ} \mathrm{C}$ and $37^{\circ} \mathrm{C}$ harshly delayed the growth and seedling propagation. However seed priming treatments neutralized the hostile properties of low and high temperature. Improved growth and healthy sprout development allocated to seed priming linked with better chlorophyll content, improved anti-oxidant enzymatic activities, and decreased MDA content in a primed seed. Priming treatments exhibited trend in the fashion of NTW $>\mathrm{H} 2 \mathrm{O} 2>$ $\mathrm{CaCl} 2>\mathrm{SA}$ at low temperature, $\mathrm{NTW}>\mathrm{CaCl} 2>\mathrm{H} 2 \mathrm{O} 2>\mathrm{SA}$ at optimal temperature and showed NTW $>\mathrm{H} 2 \mathrm{O} 2>\mathrm{CaCl} 2>$ SA at high temperature

It was concluded from all results that nano-priming is most efficient in rate of germination, seedling growth, and chlorophyll content and oxidative enzymes systems in all three temperatures. Nanometer Qiangdi 863 Nano disc has strong light absorbing properties and ceramic material act as carrier. The ceramic material has high absorbing activity which promoting chemical reaction of nano treated water. Qiangdi nano-863 disc emits electromagnetic waves that produced declustered water molecules or activated water molecules of high energy and entered into plant cell stimulated the metabolism. So, temperature had no effect on reaction rate, solubility and kinetic energy of water molecule. But temperature fluctuations affect other priming agents e.g. $\mathrm{CaCl}_{2}, \mathrm{H}_{2} \mathrm{O}_{2}$ and SA. Nano priming showed most persistent results at low, Optimal and high temperature conditions. Therefore, it recommended as remedial technological to cop temperature stress for rice production. Ultimate it will contribute toward food security.

\section{Acknowledgements}

The authors are thankful to Prof. Shiwen Haung from the State key laboratory of Rice Biology, Hangzhou China for providing lab and necessary facilities.

Funding

The publication of the present work is supported by the Natural Science Basic Research Program of Shaanxi Province (grant no. 2018JQ5218) and the National Natural Science Foundation of China (51809224), Top Young Talents of Shaanxi Special Support Program.

\section{References}

ACHARYA, P., JAYAPRAKASHA, G.K., CROSBY, K.M., JIFON, J.L. and PATIL, B.S., 2020. Nanoparticle-Mediated Seed Priming Improves Germination, Growth, Yield, and Quality of Watermelons 
(Citrullus lanatus) at multi-locations in Texas. Scientific Reports, vol. 10, no. 1, pp. 5037. http://dx.doi.org/10.1038/s41598-02061696-7. PMid:32193449.

AKRAM, M., MALIK M. A., ASHRAF M. Y., SALEEM M. F. and HUSSAIN, M., 2007. Competitive seedling growth and $\mathrm{K} / \mathrm{Na}$ ratio in different maize (zea mays 1.) Hybrids under salinity stress. Pakistan Journal of Botany, vol. 39, no. 7, pp. 2553-2563.

ASSOCIATION OF OFFICIAL SEED ANALYSTS - AOSA, 1990. Rules for testing seeds. Journal of Seed Technology, vol. 12, pp. 1-112.

BASHIR, K., KHAN, N.M., RASHEED, S. and SALIM, M., 2007. Indica rice varietal development in Pakistan: an overview. Paddy and Water Environment, vol. 5, no. 2, pp. 73-81. http://dx.doi. org/10.1007/s10333-007-0073-y.

BORGES, A.C.P., PIASSÃO, J.F.G., PAULA, M.O., SEPP, S., BEZ, C.F.S., HEPP, L.U., VALDUGA, A.T., PEREIRA, A.A. and CANSIAN, R.L., 2018. Characterization of oxidative stress biomarkers in a freshwater anomuran crab. Brazilian Journal of Biology $=$ Revista Brasileira de Biologia, vol. 78, no. 1, pp. 61-67. http://dx.doi. org/10.1590/1519-6984.04816. PMid:28614422.

CHANDRASEKARAN, U., LUO, X., WANG, Q. and SHU, K., 2020. Are there unidentified factors involved in the germination of nanoprimed seeds? Frontiers in Plant Science, vol. 11, pp. 832. http://dx.doi.org/10.3389/fpls.2020.00832. PMid:32587599.

CHRISTOU, A., MANGANARIS, G.A. and FOTOPOULOS, V., 2014. Systemic mitigation of salt stress by hydrogen peroxide and sodium nitroprusside in strawberry plants via transcriptional regulation of enzymatic and non-enzymatic antioxidants. Environmental and Experimental Botany, vol. 107, pp. 46-54. http://dx.doi.org/10.1016/j.envexpbot.2014.05.009.

CHUN, H.U.A. and REN-LEI, W.A.N.G., 2003. Changes of SOD and CAT activities and MDA content during senescence of hybrid rice and three lines leaves. Xibei Zhiwu Xuebao, vol. 23, no. 3, pp. 406-409.

DASS, A., SHEKHAWAT, K., CHOUDHARY, A. K., SEPAT, S., RATHORE, S. S., MAHAJAN, G. and CHAUHAN B. S., 2017. Weed management in rice using crop competition-a review. Crop Protection, vol. 95, pp. 45-52.

DATTA, A. and ADHYA, T.K., 2014. Effects of organic nitrification inhibitors on methane and nitrous oxide emission from tropical rice paddy. Atmospheric environment, vol. 92, pp. 533-545.

DING, C.-K. and YI WANG, C., 2003. The dual effects of methyl salicylate on ripening and expression of ethylene biosynthetic genes in tomato fruit. Plant Science, vol. 164, no. 4, pp. 589-596. http://dx.doi.org/10.1016/S0168-9452(03)00010-4.

EL-MAAROUF-BOUTEAU, H.A.Y.A.T., SAJJAD, Y., BAZIN, J., LANGLADE, N., CRISTESCU, S.M., BALZERGUE, S., BAUDOUIN, E. and BAILLY, C., 2015. Reactive oxygen species, abscisic acid, and ethylene interact to regulate sunflower seed germination. Plant, Cell $\mathcal{E}$ Environment, vol.38, no. 2, pp. 364-374. http://dx.doi.org/10.1111/ pce.12371. PMid:24811898.

FAHAD, S., HUSSAIN, S., SAUD, S., KHAN, F., HASSAN, S., NASIM, W. ARIF, M., WANG, F. and HUANG, J., 2015. Exogenously applied plant growth regulators affect heat-stressed rice pollens. Journal of Agricultural Crop Sciences, vol. 202, pp. 139-150.

FAROOQ M., BASRA, S.M.A., REHMAN, H., HUSSAIN, M. and AMANAT, Y., 2007a. Pre-sowing salicylate seed treatments improve the germination and early seedling growth in fine rice. Pakistan Journal of Agricultural Sciences, vol. 44, pp. 16-23.

FAROOQ, M., BASRA, S.M.A. and KHAN, M.B., 2007b. Seed priming improves the growth of nursery seedlings and the yield of transplanted rice. Archives of Agronomy and Soil Science, vol. 53, no. 3, pp. 315-326. http://dx.doi. org/10.1080/03650340701226166.
FISCHER, G., SHAH, M., TUBIELLO, F.N. and VAN VELHUIZEN, H.. 2005. Socio-economic and climate change impacts on agriculture: an integrated assessment, 1990-2080. Philosophical Transactions of the Royal Society of London. Series B, Biological Sciences, vol. 360, no. 1463, pp. 2067-2083.http://dx.doi.org/10.1098/ rstb.2005.1744. PMid:16433094.

FOOD AND AGRICULTURE ORGANIZATION - FAO, 2005. Food and Agriculture Organization of the United Nations. Rome: FAO.

GILL, S.S. and TUTEJA, N., 2010. Reactive oxygen species and antioxidant machinery in abiotic stress tolerance in crop plants. Plant Physiology and Biochemistry, vol. 48, no. 12, pp. 909-930. http://dx.doi.org/10.1016/j.plaphy.2010.08.016. PMid:20870416.

HILL, H.J., CUNNINGHAM, J.D., BRADFORD, K.J. and TAYLOR, A.G., 2007. Primed lettuce seeds exhibit increased sensitivity to moisture content during controlled deterioration. Horticultural Science (Prague), vol. 42, pp. 1436-1439.

HUSSAIN, S., KHAN, F., HUSSAIN, H.A. and NIE, L., 2016. Physiological and biochemicals mechanisms of seed priming-induced chilling tolerance in rice cultivars. Frontiers of Plant Science, vol. 9, pp. 116. http://dx.doi.org/10.3389/fpls.2016.00116.

HUSSAIN, S., PENG, S., FAHAD, S., KHALIQ A., HUANG, J., CUI, K. and NIE, L., 2015. Rice management interventions to mitigate greenhouse gas emissions: a review. Environmental Science and Pollution Research International, vol. 22, no. 5, pp. 3342-3360. http://dx.doi.org/10.1007/s11356-014-3760-4. PMid:25354441.

JEEVAN KUMAR, S.P., RAJENDRA PRASAD, S., BANERJEE, R. and THAMMINENI, C., 2015. Seed birth to death: dual functions of reactive oxygen species in seed physiology. Annals of Botany, vol. 116, no. 4, pp. 663-668. http://dx.doi.org/10.1093/aob/ mcv098. PMid:26271119.

JELLER, H., PEREZ, S.C. and RAIZER, J., 2003. Water uptake, priming, drying and storage effects inCassia excelsa Schrad seeds. Brazilian Journal of Biology $=$ Revista Brasileira de Biologia, vol. 63, no. 1, pp. 61-68. http://dx.doi.org/10.1590/S1519-69842003000100008. PMid:12914415.

JERÔNIMO, G.T., SPECK, G.M., CECHINEL, M.M., GONÇALVES, E.L.T. and MARTINS, M.L., 2011. Seasonal variation on the ectoparasitic communities of Nile tilapia cultured in three regions in southern Brazil. Brazilian Journal of Biology = Revista Brasileira de Biologia, vol. 71, no. 2, pp. 365-373. http://dx.doi.org/10.1590/S151969842011000300005. PMid:21755153.

JISHA, K.C. and PUTHUR, J.T., 2016. Seed priming with betaamino butyric acid improves abiotic stress tolerance in rice seedlings. Rice Science, vol. 23, no. 5, pp. 242-254. http://dx.doi. org/10.1016/j.rsci.2016.08.002.

JUN-RONG, H., AI-JUAN, W., GUO-RONG, W., LIAN-MENG, L. and SHI-WEN, H., 2016. Quality of irrigated water with nanometer pottery tray treatment and its effects on seed soaking. Rice Science, vol. 23, no. 2, pp. 88-95. http://dx.doi.org/10.1016/j. rsci.2016.02.003.

LAL, S.K., KUMAR, S., SHERI, V., MEHTA, S., VARAKUMAR, P., RAM, B., BORPHUKAN, B., JAMES, D., FARTYAL, D. and REDDY, M.K., 2018. Seed priming: an emerging technology to impart abiotic stress tolerance in crop plants. In: A. RAKSHIT and H. SINGH, eds. Advances in seed priming, pp. 41-50. Singapore: Springer. http://dx.doi.org/10.1007/978-981-13-0032-5_3.

LARIGUET, P., RANOCHA, P., DE MEYER, M., BARBIER, O., PENEL, C. and DUNAND, C., 2013. Identification of a hydrogen peroxide signaling pathway in the control of light-dependent germination in Arabidopsis. Planta, vol. 238, no. 2, pp. 381-395. http://dx.doi. org/10.1007/s00425-013-1901-5. PMid:23716184.

MAHAKHAM, W., SARMAH, A.K., MAENSIRI, S. and THEERAKULPISUT, P., 2017. Nanopriming technology for enhancing germination and 
starch metabolism of aged rice seeds using phytosynthesized silver nanoparticles. Scientific Reports, vol. 7, no. 1, pp. 8263. http://dx.doi.org/10.1038/s41598-017-08669-5. PMid:28811584.

MARSCHALL, M. and PROCTOR, M.C., 2004. Are bryophytes shade plants? Photosynthetic light responses and proportions of chlorophyll a, chlorophyll b and total carotenoids. Annals of Botany, vol. 94, no. 4, pp. 593-603. http://dx.doi.org/10.1093/ aob/mch178. PMid:15319230.

MOHAJERI, F., RAMROUDI, M., TAGHVAEI, M. and GALAVI, M., 2017. Effects of seed priming on chlorophyll content and yield components of pinto beans. International Journal of Biology, Pharmacy and Allied Sciences, vol. 6, pp. 1069-1085.

PAPARELLA, S., ARAÚJO, S.S., ROSSI, G., WIJAYASINGHE, M., CARBONERA, D. and BALESTRAZZI, A., 2015. Seed priming: state of the art and new perspectives. Plant Cell Reports, vol. 34, no. 8, pp. 1281-1293. http://dx.doi.org/10.1007/s00299015-1784-y. PMid:25812837.

REHMAN, H., BARSA, S.M.A., FAROOQ, M., AHMED, N., and AFZAL, I., 2011. Seed priming with $\mathrm{CaCl}_{2}$ improves the stand establishment, yield, and quality attributes in direct-seeded rice (Oryza sativa). International Journal of Agriculture and Biology, vol. 13, no. 5, pp. 5.

RIBANT, J.M., BANZIGER, M. and HOISINGTON, D., 2002. Genetic dissection and plant improvement under abiotic stress conditions: drought tolerance in maize as an example JIRCAS. Working Reports, vol. 85, pp. 92.

RUAN, S., XUE, Q. and TYLKOWSKA, K., 2002a. Effects of seed priming on germination and health of rice (Oryza sativa L.) seeds. Seed Science and Technology, vol. 30, pp. 451-458.

RUAN, S., XUE, Q. and TYLKOWSKA, K., 2002b. The influence of priming on germination of rice (Oryza sativa L.) seeds and seedling emergence and performance in flooded soils. Seed Science and Technology, vol. 30, pp. 61-67.

SCREMIN-DIAS, E., LORENZ-LEMKE, A.P. and OLIVEIRA, A.K., 2011. The floristic heterogeneity of the Pantanal and the occurrence of species with different adaptive strategies to water stress. Brazilian Journal of Biology = Revista Brasileira de Biologia, vol .
71, no. 1, suppl. 1, pp. 275-282. http://dx.doi.org/10.1590/ S1519-69842011000200006. PMid:21537600.

SONG, X., ZHANG, L., ZHAO, J., XU, Y., SUN, Z., LI, P. and YU, J., 2011. Preparation of calcium sulfate whiskers using waste calcium chloride by reactive crystallization. Crystal Research and Technology, vol. 46, no. 2, pp. 166-172. http://dx.doi. org/10.1002/crat.201000420.

WAHID, A., PERVEEN, M., GELANI, S. and BASRA, S.M.A., 2007. Pretreatment of seed with $\mathrm{H}_{2} \mathrm{O}_{2}$ improves salt tolerance of wheat seedlings by alleviation of oxidative damage and expression of stress proteins. Journal of Plant Physiology, vol. 164, no. 3, pp. 283-294. http://dx.doi.org/10.1016/j.jplph.2006.01.005. PMid:16545492.

WANG, H., WANG, H., SHAO, H. and TANG, X., 2016. Recent advances in utilizing transcription factors to improve plant abiotic stress tolerance by transgenic technology. Frontiers in Plant Science, vol. 7, pp. 67. http://dx.doi.org/10.3389/fpls.2016.00067. PMid:26904044.

WOJTYLA, Ł., LECHOWSKA, K., KUBALA, S. and GARNCZARSKA, M., 2016. Different modes of hydrogen peroxide action during seed germination. Frontiers in Plant Science, vol. 7, pp. 66. http:// dx.doi.org/10.3389/fpls.2016.00066. PMid:26870076.

YAN, S. and DONG, X., 2014. Perception of the plant immune signal salicylic acid. Current Opinion in Plant Biology, vol. 20, pp. 64-68. http://dx.doi.org/10.1016/j.pbi.2014.04.006. PMid:24840293.

YOUNAS, A., YOUSAF, Z., RIAZ, N., RASHID, M., RAZZAQ Z., TANVEER, M. and HUANG, S., 2020. Role of nanotechnology for enhanced rice production. In: R. MEENA, eds. Nutrient dynamics for sustainable crop production. Singapore: Springer, pp. 315-350. http://dx.doi.org/10.1007/978-981-13-8660-2_11.

ZHENG, M., TAO, Y., HUSSAIN, S., JIANG, Q., PENG, S., HUANG, J., CUI, K. and NIE, L., 2016. Seed priming is dry direct-seeded rice: consequences for emergence, seedling growth, and associated metabolic events under drought stress. Plant Growth Regulation, vol. 78, no. 2, pp. 167-178. http://dx.doi.org/10.1007/ s10725-015-0083-5. 